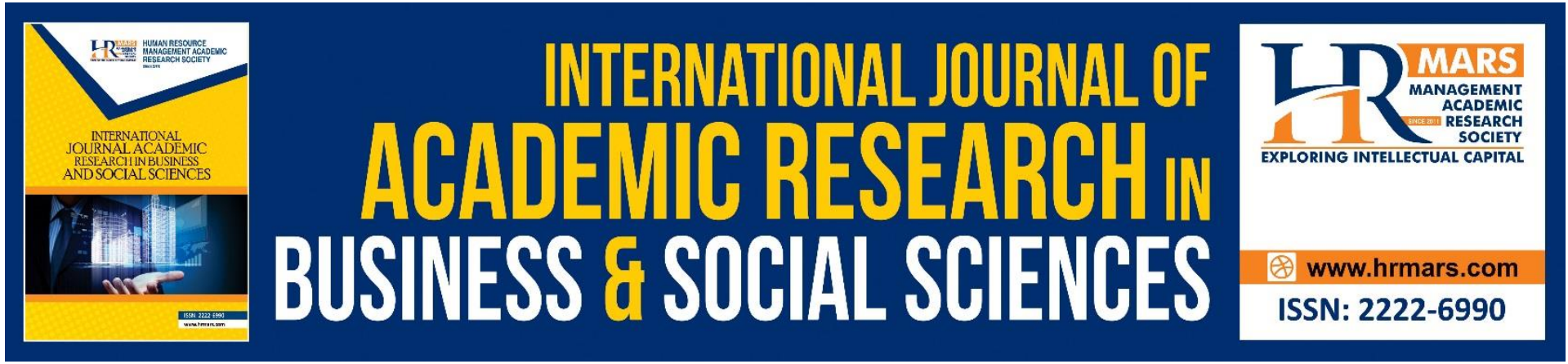

\title{
The Needs Analysis for the Affixes Innovation Kit for Students of Tamil Vernacular Schools
}

\section{Siva Perumal, Vijayaletchumy Subramaniam, Kavenia Kunasegran}

To Link this Article: http://dx.doi.org/10.6007/IJARBSS/v11-i8/10741

DOI:10.6007/IJARBSS/v11-i8/10741

Received: 19 June 2021, Revised: 22 June 2021, Accepted: 01 August 2021

Published Online: 13 August 2021

In-Text Citation: (Perumal et al., 2021)

To Cite this Article: Perumal, S., Subramaniam, V., \& Kunasegran, K. (2021). The Needs Analysis for the Affixes Innovation Kit for Students of Tamil Vernacular Schools. International Journal of Academic Research in Business and Social Sciences, 11(8), 412-436.

Copyright: (c) 2021 The Author(s)

Published by Human Resource Management Academic Research Society (www.hrmars.com)

This article is published under the Creative Commons Attribution (CC BY 4.0) license. Anyone may reproduce, distribute, translate and create derivative works of this article (for both commercial and non-commercial purposes), subject to full attribution to the original publication and authors. The full terms of this license may be seen at: http://creativecommons.org/licences/by/4.0/legalcode

Vol. 11, No. 8, 2021, Pg. 412 - 436

http://hrmars.com/index.php/pages/detail/IJARBSS

JOURNAL HOMEPAGE

Full Terms \& Conditions of access and use can be found at http://hrmars.com/index.php/pages/detail/publication-ethics 


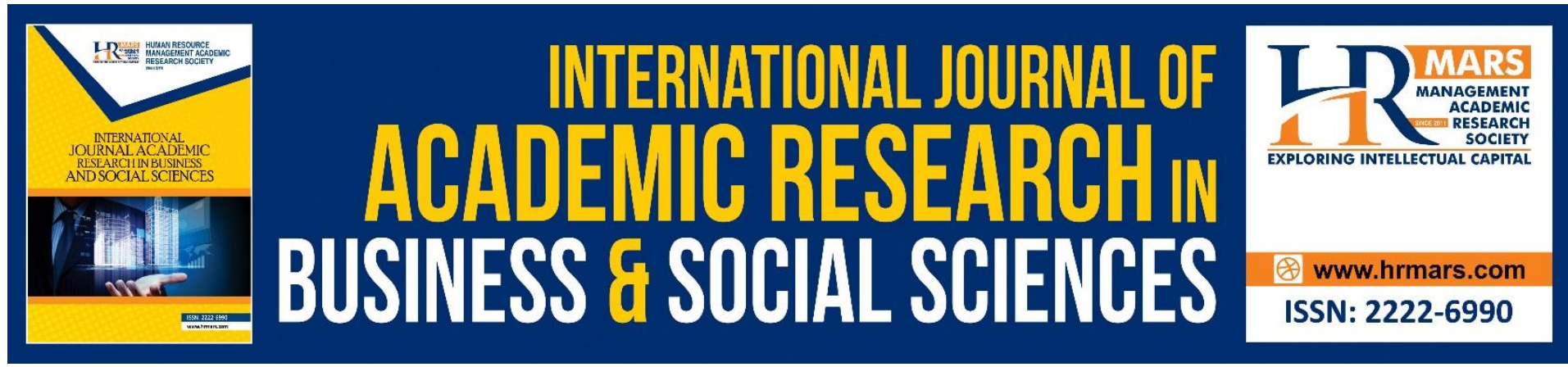

\title{
The Needs Analysis for the Affixes Innovation Kit for Students of Tamil Vernacular Schools
}

\author{
Siva Perumal, $\mathrm{PhD}^{1}$, Vijayaletchumy Subramaniam, $\mathrm{PhD}^{2}$, \\ Kavenia Kunasegran ${ }^{3}$ \\ Department of Malay Language, Faculty of Modern Languages and Communication, UPM \\ Email: profvijaya.upm@gmail.com
}

\begin{abstract}
The mastery of using affix words among SJKT or Tamil vernacular schools should be taken seriously. This study aims to identify the need for the prefix/suffix word innovation kit in Malay Language for Tamil vernacular school students. This innovation kit plays the role as an alternative material for teaching and learning (PdPc) activities using prefix and suffix words, also academic support materials to diversify the teaching technique also prepare a variation of questions that concern the mastery of words with prefixes and suffixes. This study applies the Design and development Research Approach introduced by Richey and Klien (2007). This study involves the need analysis that is divided into three parts. The first part is the survey study involving 163 students. The data obtained was analysed through the descriptive statistics using the software called Statistical Package for the Social Science (SPSS) version 25.0. The interpretation of the needs analysis depends on the mean value and the standard deviation. The second part of this study involves the evaluation test on the prefix/suffix word skills to measure the level of mastery of this area among the students. The third part covers the semi-structured interview on the Malay Language Head Teacher to get some feedback on the need to construct the prefix/suffix word innovation kit. Its development will be able to improve the mastery of prefix/suffix words among Tamil vernacular school students.
\end{abstract}

Keywords: Evaluation Test, Prefixes, Suffixes, Affixes, Borrowed Affixes, Prefix/Suffix Word Innovation Kit

\section{Introduction}

In this globalised era, the world of education has been experiencing a very fast-paced development. Responding to this, Ministry of Education Malaysia has taken the steps to revamp the education system and produce the Malay Language Curriculum Standard'. The main motive for the formulation of the Primary School Malay Language Standard Curriculum (SK Malay Language) is to give priority to the Content Standard (SK) and Learning Standard (SP) that should be mastered by every student. This curriculum standard encompasses the knowledge, skills and the moral values that must be emphasised among primary school students. In actual fact, SK Malay Language really prioritises the teaching method of Malay Language at all primary schools. At the same time, the teaching and learning technique (PdPc) 
that is diverse, also the different interest and tendency among the students are prioritised. Next, the co-academic activities also play the role to consolidate the students' language skills other than becoming the catalysts to pioneer SK Malay Language (Ministry of Education Malaysia, 2011).

A good Malay Language mastery can be applied using a modular which is skills divided into small units called a module. Following this, five modules, Listening and Speaking Module, Reading Module, Writing Module, Language Arts Module and Grammar Module produced for the subject of Malay Language. It is found that the Listening and Speaking Module, Reading Module and Writing Module have been designed based on four skills namely listening skills, speaking skills, reading skills and writing skills. The Language Art and Grammar Modules function as the supporter of other modules to strengthen students' language capability. (Ministry of Education Malaysia, 2011)

The Grammar module stresses on the aspect of morphology and syntax of Malay Language which should be mastered by every student. Thus, the importance in learning grammar well must be instilled within every student. Thus, the teaching of Malay Language's morphology and syntax must be implemented with a more effective technique so that every student can master the grammar and use it the best way possible. It is a coincidence that the language system encompasses the grammar, spelling system, pronunciation, vocabulary and proverbs. The language system used in the teaching and learning of Malay Language motivates the students to practise standard Malay Language well (Ministry of Education Malaysia, 2011).

Based on the Malay Language Assessment Curriculum Standard Document, Year 1 students need to understand and identify the use of prefixes $m e-$, men-dan mem- by context. Year 2 students need to understand the use of the prefixes meN- and beR-by context. Year 3 students should understand and identify the use of prefixes beR-, men-, di- and mem- and the suffixes $-i,-k a n$ and-an according to the context. Clearly, Year 1 and 2 students are required to master the prefixes whereas Year 3 students need to master prefixes and suffixes (Primary School Standard Curriculum Document Standard, 2011).

For level 2, Year 4 students are expected to understand and use the prefixes $m e N, p e N, b e R$, and teR correctly according to the context. Year 5 students need to understand and use suffixes ke...an, peN...an and meN...kan and borrowed affixes like maha-, -wan, -man, tata-, and pra-correctly. Year 6 students need to understand and use affixes in various situations correctly. Among the language aspects that they need to master are the prefixes, affixes and suffixes (Ministry of Education Malaysia, 2011). In general, students in Type-schools should master four types of aspects, namely prefix, suffix, affix and borrowed affixes. They are not required to master insertions. This study will measure the mastery of affixes among SJK students based on the standard that has been decided in the SJK text books and in the Curriculum and Assessment Standard Document.

Although various efforts have been realised by the government to consolidate the mastery of Malay Language, but the Malay Language achievement at the Primary School Assessment level (UPSR) for Tamil-Type Schools in the district of Klang from 2012 to 2016 is still at moderate level (Klang Education Office 2017). The fail percentage of Malay Language comprehension and writing in 13 Type-schools in Klang is between $38 \%$ and $46 \%$ in 5 
consecutive years. The number of people who fail in both papers should be zero. This statistics leaves a great impact towards the effort in increasing the quality of mastery of Malay Language among the SJKT students. Most students who entered the secondary school are Indian students as their mastery in the subject is below satisfactory level.

Among the factors as to why SJKT students lack the mastery in Malay Language is because Malay Language is the second language in SJKT, Malay Language tend to code-switch in the teaching of Malay Language and students do not have the initiative to converse in Malay Language. Affixes is one of the grammatical aspects in Malay Language. New words are normally formed through the affixes process. Thus, they are often used in the Malay Language be it through speeches or through writing. Students of Tamil schools need to master affixes as every part in both papers of the subject contains the element of affixes.

The issue can be strengthened through a pilot study done on 60 intermediate students from two schools. They answered 25 multiple-choice objective questions about prefixes, suffixes, affixes as well as borrowed affixes. The study finding shows that $76 \%$ of the students do not master prefixes, $80 \%$ do not know much about suffixes, $15 \%$ students master affixes and $20 \%$ students master borrowed affixes. The pilot study clearly reflects a weak mastery of affixes among SJKT students. This finding is in line with that by Norsidah (2010) which is, $80 \%$ nonMalay students are weak in mastering grammar. The application of interesting teaching aid especially language games can stimulate their interest to learn Malay Language as their B2 (Aliza \& Zamri, 2016).

Word insertion is a method of word formation contained in Malay Language. Almost all of the basic words in Malay Language experience insertion of some kind. Even so, every student was found to have done errors in prefixes, suffixes, affixes and borrowed affixes as they are still in doubt and they do not master these correctly. Meanwhile, the weakness in mastering this insertion words has become the obstacle to Indian students to understand the meaning also the function of these insertions in the comprehension and writing of the Malay Language. As the consequence, students from Tamil schools still have to face the problem of mastering insertions. The lack of understanding in the use of these insertion words correctly has led to them using the insertions blindly as they write sentences and paragraphs (Vijayaletchumy \& Siva, 2020). Therefore, the dynamic approach that serves as a stepping stone to the innovation in education must be done to increase students' knowledge in mastering these insertion words. The conventional learning must be made easier with the use of the support kit so that students can learn the insertion words in a more effective way. In that way, researcher identifies the need for an affix word innovation kit in Malay Language for TamilType School students in line with the first objective of the study.

The study is done based on the researcher's need to get the data to produce affix words innovation kit based on DSKP and the text book for SJK students. The study objective for the needs analysis phase is to identify the needs for the right affix innovation kit for the students and the teachers so that they can handle the lessons on that aspect, well. 


\section{Literature Review \\ Studies on Errors in Insertion Words}

The study done by Amirra \& Vijayaletchumy (2019) aims to discuss the type of error in prefixes and suffixes based on Corder's Error Analysis Theory (1973). They also conducted this study to identify the reasons as to why Tamil-Type School students (SJKT) were not able to master prefixes and suffixes. A total of 50 Indian students were chosen as the sample of this study. The sample comprises of Year Five students from Tamil Type School in Serdang. The written test about prefixes and suffixes became the instrument while Corder's Error Analysis Theory (1973) became the theory used. The observation method is also used in this study. The study outcome explains that all the students failed in mastering prefixes and suffixes. This is the initial step to increase students' understanding in affixes so that they apply affixes that they master in the writing. However, Alhaadi \& Zaitul (2018) carried out a study to know and analyse the language in terms of the affixes using Corder's Error Analysis Theory (1981) to analyse the data. The study done by Amirra\& Vijayaletchumy (2019) delved into the types of errors concerning prefixes and suffixes only, as mistakes done by the Indian students by applying Corder's Error Analysis Theory (1973). It has given an idea to the researcher to carry out a study on the prefixes, suffixes, affixes as well as borrowed affixes using Corder's Error Analysis Theory (1981) and Multiple Intelligence Theory.

The research paper carried out by Nurul\& Maisarah(2018) aims to address the use of prefix beR- and affixes beR-...-an through the applications Nearpod and Google Docs aided by Active Learning Approach. Through their studies, the use of the prefix beR-and affix beR-...-an is the weakness of the students of Form 3 Ekspres in the use of affixes. This is because only $38 \%$ students can answer the questions concerning the prefix beR- and affix beR-...-an correctly. The study outcome reveals that students take part proactively in building and gaining their knowledge and experience about the prefix beR- and affix beR-...-an. Malay Language teachers are very satisfied with the students' involvement where they can explain about the meanings of the prefix beR- and affix beR-...-an in the context of the sentence. This confirmation can be proven by doing a survey at the end of the class. The survey explains that the students are confident and satisfied with the use of the prefix beR-and affix beR-...an. This study involved secondary school students and it concerns on the prefix beR-and affix beR-...an sahaja. This situation enables researcher to conduct a study on affixes involving primary school students, especially those from Tamil-Type Schools.

Alhaadi\& Zaitul(2018) carried out ths study to know and analyse the language from the aspect of affixes involving Year 5 Chinese students in writing. Normally, the language errors made through the conversation will be carried away on the writing of the second language. The material for this study is the answer script under Section $C$ writing paper, involving several Year 5 students from Sekolah Jenis Kebangsaan Cina Chung Hwa Telok Kemang. The purposive sampling technique is used to choose the study sample. Corder's Error Analysis Theory (1981) is used to analyse the study material. Text analysis was used as the method in this study. The finding shows that Chinese students made errors in the prefixes "di-" and "meN-". Chinese students also made errors when it comes to choosing words in writing, Ooi(2018). Ooi(2018) conducted a study on Chinese students in their use of prefixes di- and $\mathrm{meN}$ - and this enables researcher to focus on the Indian students in the mastery of prefixes, suffixes, affixes and borrowed affixes. 
According to Norhafisya(2017), prefixes is the main aspect of affixes in the morphology of Malay Language and it can contribute to wrong meaning if the affixes are used wrongly. This study aims to improve the mastery in using the prefix meN- with the help of LATIM method. The sample of the study comprises of 10 Year 4 students at a school located in Kangar, Perlis. The pre and post tests also a questionnaire were used in this study as the instrument whereas the design is quantitative. All the respondents were exposed to the LATIM method for 30 days and the post-test was carried out. The pre- and post-tests' marks for every respondent were gathered to show the difference. The respondents undergoing the post-test were given the questionnaire. It was found that all the students were really interested to master the prefix meN- using LATIM and this goes to show that the method has been able to help improve students' affix skills. The work done by Norhafisya (2017) focuses on the mastery of affixes in the use of prefix meN- only after LATIM was applied. Thus, such a gap has opened doors for the researcher to conduct a detailed study about the mastery of prefixes, suffixes, affixes dan borrowed affixes aided by the affixes innovation kit.

\section{Studies on Mastery Level of B2}

A study conducted by Kivinen(2018) in collaboration with the childcare center Espp's Finnish aims to formulate a framework for Finnish new exercise activity as B2. The respondents of this study comprise of five children aged five years old. yang berusia lima tahun. The service design model is used in this study. Children-oriented methods such as games, songs and observation are used to implement new activities in Finnish language. The finding of the study reveals that children in this childcare center have mastered new words. The finding in this study is in line with the finding of Nadwah (2014) who opined that group activities can ignite the language environment that can stimulate the use of B2 among students.

The survey method or the quantitative approach used by Noor\& Yahya(2018) in their study is to determine the relationship between the use of learning techniques and gender. A questionnaire was used as the instrument to collect the data. 150 Form 4 Melanau students from 3 secondary schools in Sarawak were selected as the respondents. The mean difference of the use of the written learning strategy between gender was identified using the t-test.

The finding from the study shows that Malay Language teachers should be using multiple teaching techniques for the writing skills to help Melanau ethnic students to master Malay Language as their B2. This finding is consistent with the study by Nur Khadijah et al. (2014). It is thought to be relevant because the researcher also used the t-test to identify the significant relationship between the use of the affix word innovation kit and the normal teaching method in the teaching and learningaffixes in class Chinese students from the Chinese-Type primary schools (SJKC) Batu 14 Hulu Langat, Selangor recorded a low pass percentage in the paper Malay Language comprehension in the Ujian Penilaian Sekolah Rendah (UPSR). Evidently, the students really faced the issue of learning Malay Language as their B2. In relation to this, Ooi\& Vijayaletchumy(2017) studied the factors leading to the learning of the Malay Language among Chinese students. 77 students from Level 2 that had failed in the Malay Language paper were selected as the sample of the study, while the Interaction Theory was used in this study. Those who are really good at communicating in their mother tongue did not learn Malay Language very well. The survey form was used as a tool of the study and the data obtained was calculated in the form of percentage. The exercises, the environment, interest and attitude are among the factors that influence the learning of the Malay Language among 
the Chinese students. At the same time, Roshidah (2015) finds that there is a linguistic difference between the first language and the second language causing disturbance and issues to the students to learn the second language. The study done by Ooi\& Vijayaletchumy(2017) serves as the guidance in empowering the Malay Language among nonnative speakers aided by the affixes innovation kit.

The effectiveness in using the circular map and the flow chart in increasing the mastery in writing narrative essays among Chinese students in an SJKC was the main highlight for Noor\& Yahya(2016). The control and treatment groups involving 30 Chinese students respectively were used in this quasi-experimental study. The ones from the experimental group underwent teaching and learningof Malay Language using the circular map and the flow chart. The pre and post-tests data were analysed using the t-test and the ANOVA test. There is a significant difference on the writing of narrative essay for the experimental group in the ttest. The teaching and learning of Malay Language with the help of these teaching aids is able to increase the achievement of the Chinese students in writing narrative essays. The findings obtained from Noor\& Yahya(2016) lead the way for the researcher to prove that the use of the affixes innovation kit is able to enhance the mastery of affixes among non-Malay students.

\section{Studies on the Use of Games in Teaching and Learning}

The surge of creativity in students in game-based learning has been studied by Maja (2019). The qualitative and quantitative methods were used in this study. Creativity test, survey and formative evaluation were carried out to collect the data. This study was done in two primary schools in the town of Osijek, Kroasia. It was revealed that game-based teaching truly stimulates students' creativity to follow the lessons in class. This is consistent with the finding of Nur (2012) who stated that there is a positive change among students with the game or play method in teaching. The gap created from the study of Maja (2019) enables the researcher to go further into the study by designing an innovation kit that can help stimulate students' creativity by learning affixes more easily.

The effectiveness of the play technique in consolidating the skill of translating proverbs was studied by Nurul Hudaet al. (2017). Students at the public higher learning institutions (IPTA) in Melaka were the sample and observation, pre and post-tests were adopted as the study instruments. Students' failure in answering the questions, their poor results in the tests done also poor involvement are among the outcome obtained through the observation and analysis of the work sheet. This problem has been solved by introducing card games to foreign students aiming to increase the skills in translating proverbs. This argument closely relates to the point made by Sri \& Zawiyah (2016) who highlighted the effectiveness in the card games in Civic subject. The use of this activity shows that foreign students are really interested and have the confidence in following the teaching and learning of proverbs. They also have high motivation to get involved in the card games activities with the element of translating proverbs.

The study done by Jorge (2016) is based on gamification and game-based learning (GBL). It is shown that students are more motivated and work actively in this kind of learning approach. dan bergiat aktif dalam pembelajaran dengan penggunaan kaedah permainan. The study outcome is very much related to the study conducted by Sharifah\& Aliza (2012) and Guat(2015) who show that teachers have the awareness that fun learning is able to increase 
the teaching performance in the classroom. The finding also explains that educators must adapt to the best approach like the game theory in line with the $21^{\text {st }}$ century learning.

\section{Study Methodology Needs Analysis Phase}

The needs analysis phase is the first phase in this teaching and learning method seeking to recognise and evaluate the needs that are to be evaluated so that decisions wished to be achieved by researcher can be determined (McKillip 1987). This current work seeks to get some feedback from the students and teachers about the need to have the affix word innovation kit that will be devised to overcome the existing issues. This statement is supported by Richey and Klein (2007) with the opinion that the strength in the design and the kit development is to resolve the problems in a specific context. Saedah, Norlidah, Dorothyt, and Zaharah(2013) maintain that the needs analysis studies partly looks into the design study and the product development. Thus, needs analysis study is done to know the issue that exists prior to the designing of the affix word innovation kit.

The main motive of the analysis phase is to identify the root cause of the problem (Branch, 2009; Gagne, Wager, Golas, \& Keller, 2005) and take steps to overcome any arising issues (Reinbold, 2013). The needs analysis phase takes the role as an information giver to determine the design and development of the product in phase 2 (Gagne et al., 2005). Stemming from that, the needs analysis study is done to know the method of the teaching that is more meaningful to help students master affixes easier. The finding from the analysis phase is applied in the design phase and development of the affix word innovation kit (DeWitt, 2010). It is in this phase that the researcher designed the needs analysis based on their reading from the literature. It enables the researcher to identify the needs to build an affix word innovation kit for SJK students. This phase stresses on the level of mastery of affixes among SJK students through questionnaires and affixes achievement tests. 


\begin{tabular}{|c|c|}
\hline $\begin{array}{r}\text { S } \\
\text { Needs An }\end{array}$ & s Phase \\
\hline $\begin{array}{l}\text { Purposes } \\
\text { - Getting information about the need } \\
\text { for a kit } \\
\text { - Orienting on mastering affixes- } \\
\text { prefixes, affixes for groups of } \\
\text { students in the following areas } \\
\text { - Students' perception about the level } \\
\text { of use of prefixes, suffixes, affixes } \\
\text { and borrowed affixes } \\
\text { - Teacher's perception about the use } \\
\text { of the support kit in the teaching } \\
\text { and learning of affixes. }\end{array}$ & $\begin{array}{l}\text { Findings } \\
\text { - Data about the need for a kit } \\
\text { - Orienting on mastering affixes- } \\
\text { prefixes, affixes for groups of } \\
\text { students in the following areas } \\
\text { - Data about the use of prefixes, } \\
\text { suffixes, affixes and borrowed } \\
\text { affixes from students' perception } \\
\text { - Data to test students' mastery on } \\
\text { prefixes, suffixes, affixes and } \\
\text { borrowed through tests } \\
\text { - Data on teacher's perception about } \\
\text { the use of the support kit } \\
\text { concerning affixes in teaching and } \\
\text { learning affixes more effectively }\end{array}$ \\
\hline $\begin{array}{c}\text { Design and Del } \\
\text { Evaluation }\end{array}$ & $\begin{array}{l}\text { oment Phase } \\
\text { ysis Phase }\end{array}$ \\
\hline \multicolumn{2}{|c|}{ End } \\
\hline
\end{tabular}

Diagram 1: Flow chart of the needs analysis (Adapted from Zanariah, 2017).

\section{Procedure}

In this phase, researcher carried out a survey in five primary schools using the questionnaire, affixes achievement test and interview involving four stages, instrument construction, pioneer study, instrument administration and finally data analysis. Initially, researcher had conducted the questionnaire by adapting the instrument from Ooi(2018) whereas the questions of affixes test were taken from the Type-School Malay Language text book from Year One to Year Five. This adaptation process is based on the adaptability of this study. Next, a pilot study was done at a selected School-Type to know the validity and the reliability of the questionnaire. Next, researcher distributed the questionnaire and the achievement test to five selected SJKs in Selangor and interviewed five Heads of the Malay Language teachers. Finally, researcher had analysed the finding of the study. The finding from this needs analysis phase becomes the guidance to design and develop the second phase. The respondents involved in the needs analysis are divided into teachers and students. According to Krohn (2008), students, teachers, or undergraduates are the main resources to get information in this needs analysis phase. As this study focuses on the construction of the affix word innovation kit for primary school students, the respondents involved were students from SJK. The sampling in this study is purposive sampling involving Year 5 students from SJKT. Also, the sample used in the pilot study is 60 students from two schools. They were chosen based on the final results of Malay Language paper 1 and 2 in 2018. A total of 163 weak Year 5 students especially in Malay Language subject based on teacher's observation and their school achievement test from every school became the actual subjects 
of the study. They obtained marks between 0 and 39\% in the first monthly test last January. These Year 5 students were chosen as they were at the intermediate level at school, and they should have mastered prefixes, suffixes, affixes and borrowed affixes from Year 1 to Year 4. With this, their level of mastery can serve as the guidance and substantial evidence for the launching of affixes learning strategy as they embark upon their Year 6.

\section{Study Tools}

The questionnaire, the affixes achievement test and the interview related to the objective and the purpose of the study are the instruments required to construct the prefix/suffix word innovation kit. The tools are further described below:

\section{Questionnaire}

To achieve the first objective of this study, which is to identify the need for the affix word innovation kit based on DSKP, the questionnaire and interview methods are used in this study. At the first stage, researcher built the questionnaire by adapting to the instrument from Ooi(2018) for the collection of quantitative data. The questionnaire form was distributed to the study respondents comprising of 163 SJKT students. Respondents were given a period of 20 minutes to answer the question in the form of questionnaire. An interview was also done earlier by the researcher with the students who are also the respondents in this study to give them the opportunity to make preparation without pressure and time-constraint to obtain satisfactory findings.

Section A needs the respondents to fill in the personal background like gender and their class. In section $B$, respondents were required to answer ten questions about students' views about their level of mastery of affixes. The data obtained through the questionnaire was presented in the form of descriptive analysis using frequency distribution and percentage. Respondents were asked to give some feedback about all the questionnaire items by marking a choice based on the Fuzzy 5-point scale as explained in Table 1.1.

Table 1: The choice of answers for the questions in Section B of the questionnaire

\begin{tabular}{ll}
\hline Score & Description \\
\hline 1 & Strongly disagree (STS) \\
2 & Disagree (TS) \\
3 & Not sure (TP) \\
4 & Agree(S) \\
5 & Strongly Agree (SS) \\
\hline
\end{tabular}

This questionnaire contains 2 main sections, where section 1 contains the respondents' profile analysis by gender, whereas section 2 contains ten items to know students' perception about the use of prefixes, suffixes, affixes as well as borrowed affixes. The formation of item in every part of the questionnaire is formed based on the review of studies. In the context of this study, researcher uses the Fuzzy 5-point scale, or specifically strongly disagree, disagree, not sure, agree and strongly agree as stated by Ramlan \& Ghazali(2018). To measure the skills in using affixes, this questionnaire uses the interpretation method proposed by Oxford (1999) as shown in Table 1.2. Based on the Oxford Interpretation (1999), the mean score 
between 3.5 and 5.0 is regarded as high, mean score between 2.5 and 3.4 is thought of as medium and intermediate and the mean score between 1.0 and 2.4 is regarded as low.

Table 2: The Interpretation of the use of affixes skills based on Oxford Interpretation (1990)

\begin{tabular}{ll}
\hline Level & Meaan Score \\
\hline Low & $1.0-2.4$ \\
Moderate & $2.5-3.4$ \\
High & $3.5-5.0$ \\
\hline
\end{tabular}

\section{Affixes Skill Evaluation Test}

The affixes skills evaluation test that comprises of prefixes, suffixes, affixes and borrowed affixes is taken from SJKT Malay Language text book from Year 1 to Year 5 . This assessment test comprises of 20 questions and every knowledge of affixes, namely prefixes, suffixes, affixes and borrowed affixes respectively contains five questions. Students are required to fill in the blanks using the most accurate affixes. All the affixes chosen are those that should be mastered by Year 5 students according to the DSKP provided. The affixes skills evaluation test aims to measure the level of mastery of affixes among students and the language error factor made by the SJK students.

\section{Interview}

A semi-structured interview on five Heads of the Malay Language teachers was conducted in this study. The sampling technique is done purposively by selecting respondents from the homogenous group but it can give multiple kinds of information. To anticipate questions that can give better information, the interview transcription that came from the pilot study before the actual interview was accounted for. Researcher chose two respondents with the same characteristics with the sample from the actual study to be interviewed to see if the questions are appropriate. Based on the pilot study, there are two questions that have been simplified and improved. The questions improved are used in the actual study. According to Turner (2010), the significance in the interview preparation lies in the aim to maintain clear focus and selecting the right technique for the interview aims to get maximum information to answer the study question. Researcher has applied several principles in the stage of interview, which is setting appointments, choosing the right venue, explaining the purpose of the interview, showing confidence in interviewing, and giving the time for the interview to be done. Right after the interview and the data collection in the actual study are done, researcher completed the transcription and returned it to the respondent for revision. Having revised the transcription, respondent signed the interview form to confirm the interview information. The confirmed transcription was analysed using indexes. The indexing process was done by labeling codes to every respondent of the study. The interview data was categorised, sub-categorised and analysed using the coding method to produce the theme (Miles \& Huberman, 2014).

Researcher has applied several principles in the interview stage, which is setting appointments, choosing the right venue, explaining the purpose of the interview, showing 
confidence in interviewing and informing respondents about the time of the interview. Having done the actual interview and data processing, researcher completed the transcriptions and returned them to the respondents for revision. After the revision, respondents signed the confirmation form to validate the information in the interview. The verified transcriptions were analysed using indexes. This is done by labeling different codes to every respondent of the study. The interview data was categorised, sub-categorised and analysed using the coding method, to produce themes (Miles \& Huberman, 2014).

Table 3: The coding of the transcripted interviews

\section{Respondent (teacher) Code}

\begin{tabular}{ll}
\hline Respondent 1 & R1 \\
Respondent 2 & R2 \\
Respondent 3 & R3 \\
Respondent 4 & R4 \\
Respondent 5 & R5 \\
\hline
\end{tabular}

Table 1.3 shows that the interview's coding matrices are determined before being analysed using the inductive analysis method (Creswell, 2002) and further identify the respondents' themes of interaction on every answer they gave.

\section{Content Validity}

According to Jusoh 2008, the main characteristic to fulfil the requirement of content validity is through the literature study. The questionnaire and achievement test used in this study have fulfilled the reliability and validity aspects. This is because the instrument used was adapted from past studies relevant to this study.Thus, the content validity has been fulfilled (Sanchez-Franco dan Roldán, 2010). 
INTERNATIONAL JOURNAL OF ACADEMIC RESEARCH IN BUSINESS AND SOCIAL SCIENCES Vol. 11, No. 8, 2021, E-ISSN: 2222-6990 @ 2021 HRMARS

\section{Study Findings and Discussion}

Table 4: Students' perception about the use of prefixes, suffixes, affixes and borrowed affixes

\begin{tabular}{lccccccc}
\hline Students' views & STS & TS & TP & S & SS & MIN & SP \\
1 & 2 & 3 & 4 & 5 & &
\end{tabular}

I use prefixes

correctly.

I use suffixes

correctly

I use affixes

correctly.

I use

borrowed affixes correctly.

I am motivated to learn

affixes.

The mother tongue influences me in learning affixes

I am interested in learning affixes

My parents guide me in making affixes exercises

The surrounding helps me learn affixes

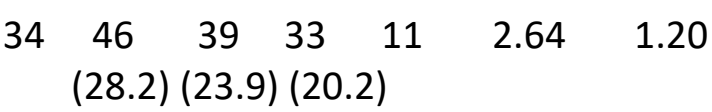

(20.9) (6.8)

$$
\begin{array}{ccccccc}
46 & 39 & 41 & 29 & 8 & 2.47 & 1.22 \\
(23.9)(25.2)(17.8) & & &
\end{array}
$$

(28.2) (4.9)

$$
\begin{array}{ll}
43 \begin{array}{llllll}
50 & 40 & 27 & 3 & 2.37 & 1.09 \\
(30.7)(24.5)(16.6) & & &
\end{array} \\
(26.4)(1.8)
\end{array}
$$

$$
\begin{array}{ccccccc}
40 & 48 & 46 & 29 & 0 & 2.39 & 1.09 \\
(29.5)(28.2)(17.8) & & & &
\end{array}
$$$$
(24.5)(0.0)
$$

$$
\begin{array}{lllllll}
35 & 39 & 39 & 26 & 24 & 2.79 & 1.33 \\
(23.9)(23.9)(15.9) & & &
\end{array}
$$

$\begin{array}{lllllll}15 & 10 & 29 & 43 & 66 & 3.83 & 1.27\end{array}$

$$
\begin{array}{lll}
(9.2) & (6.1) \quad(17.8)(26.4) \quad(40.5)
\end{array}
$$

$\begin{array}{lllllll}40 & 50 & 16 & 36 & 21 & 2.68 & 1.39\end{array}$

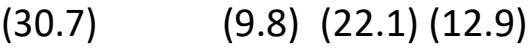

$\begin{array}{crrrrrr}52 & 53 & 22 & 26 & 10 & 2.32 & 1.24 \\ (31.9) & & & & & & \\ (32.5) & & (13.6) & (15.9) & (6.1) & & \end{array}$

I allocate some time to revise

affixes.

Note: 1- Strongly disagree, 2- Disagree, 3-Not Sure, 4- Agree, 5-Strongly Agree 
Table 4 shows students' opinions about their use of affixes. The finding explains that the mean score for the first item is 2.64 (standard deviation 1.60) and the majority of students or 46 students disagreed by using the prefixes correctly whereas $20.2 \%$ agreed with the item. The prefix meN- is one that forms active verb, be it transitive or intransitive, beR-is the prefix that forms intransitive verb, teR- is the prefix that forms passive verb or intransitive verb, and peN- is the prefix that forms noun (Nik Safiah Karim et al., 2014). Students are emphasised about the use of prefixes since Year One, and they must master this aspect correctly. Meanwhile, the problem of mastering Malay Language damogn Chinese students can be linked with the factor of their weakness in the subject of Malay Language. The study done by Norsidah, Jamaludinand Fairose(2010) illustrates that $89 \%$ Chinese students are weak in the mastery of grammar, especially in terms of the use of prefixes to form verbs and derivative nouns.

The second item looks into the use of suffixes and the mean for the item is 2.47 (standard deviation 1.22). Only 29 students agreed to this whereas $4.9 \%$ of the students strongly agreed to the use of correct suffixes. According to Zila (2015), a lot of the spelling errors made by students are affixes, and they need to be addressed quickly as the topic is the mainstay of grammar, especially in affixes involving nouns and verbs. Meanwhile, students are also said to be unable to dissect the root word from its affixes which causes them to lack the skills in using the dictionary to know the meaning and to use affixes in words clearly. This statement is consistent with that of Nathesan (2010) who explains that dictionary is scarcely used in the teaching of language.

The third item shows that $7 \%$ of the students used affixes correctly and the mean for this item is 2.37 (standard deviation 1.09). The factor of the text book that does not really emphasise on affixes has caused students to find it difficult to master this aspect. Also, Nazri\& Rosman(2014) hold the view that the text book is not tested, in terms of its reliability and validity according to the element determined in the evaluation.

For the fourth item, the mean score is 2.39 (standard deviation 1.09) and most of the students opined that they were not able to use the borrowed affixes correctly. This points to the fact that the students' knowledge on the use of borrowed affixes is alarming. This is explained by the fact that borrowed affixes begin to be learned by students in Year 5 and they need detailed explanation and ample practices to master this aspect of borrowed affixes.

The fifth item that stresses on the motivation to learn affixes shows the mean score of 2.79 and standard deviation of 1.33. It clearly shows that most of the students lack the motivation to learn affixes. This situation fits the study by Zamriand Mohamed (2006) which explains that the negative attitude of Chinese students on Malay Language is the root cause that dampens their willingness to master Malay Language. A study by Siti Sukainah\& Melor(2014) concludes that positive attitude, motivation and effort in mastering the target language is an important element that ascertains the success of a language student.

For the item of the mother tongue influencing affixes subject, 3.83 is the highest mean score in this questionnaire. It stresses on the fact that almost all of the students face the problem of Tamil influence, or their mother tongue, when learning Malay Language as their B2. Chew (2016) finds that the learning problem faced by these second language students stems from 
the lack of parental support, the lack of support from teachers and friends, that they do not read enough materials in Malay Language, that they do not really watch any show in Malay Language and that they are not active in learning Malay Language at school. The same is proven by Ooi and Vijayaletchumy (2017) who find factors like practice, environment, interest and attitude of the students lead to issues in learning Malay Language among Chinese students. YongVijayaletchumy (2012) point out that the errors in the learning of Malay Language differ among foreign students according to their demographic background, especially country of origin and mother tongue, whereas Nadwah \& Nadhilah (2014) opine that a total of $70 \%$ of the students are not able to follow the discussion in class effectively as their Arabic is poor. Based on Money (2004), Tamil students in secondary schools have learned Malay Language for at least 10 years formally but the mother tongue influence is still seen in their writing. This clearly shows that the mother tongue factor really influences them when learning their B2.

On the next item that focuses on the students' interest to learn affixes, 57 out of 163 people agreed with this item and the mean score is 2.68 (1.39). High perception and positive attitude towards Malay Language must continue to be inculcated so that students will be confident about using the language. Goh \& Ng (2004) find that attitude is the most important factor on student's failure or success in learning a foreign language. Marzalina (2004) in her study explains that students do not master Malay Language because they like to chit-chat when the lecturing is teaching and they do not focus on their learning. It is not easy to learn Malay Language as a foreign language if students are not interested, lack the willingness and the motivation (Jyh, 2005).

Item 8 notes the lowest mean score which is 2.24 (standard deviation 1.34). For this item, only 11 students agreed and 8 students strongly agreed that they get guidance from their parents when it comes to learning affixes. Most students, or a total of 36 students do not get their parents' guidance.

For item 9, the students are not sure about how the environment influences them. This is supported by the mean score of 3.06 (standard deviation 1.23) with the highest percentage of $28.8 \%$ for 'not sure'. It is evident that students do not have the awareness about the role of the environment that can influence their mastery level in affixes. A lot of studies have been done by linguists. Some of the latest ones are by Zalina(2017), Salinah (2016), Wan Zaliha\& Amanah(2015); Nur Syafiqah(2014), Yong dan Vijayaletchumy (2012) as well as Siti Baidura (2011). The language errors they study are often linked with the environmental factor, or the background of the language user. These include mother tongue, gender, their residential area and so on.

Item 10 also gives a low mean score, which is 2.26 (standard deviation 1.26) with the majority of the students not agreeing to this issue. Only few students allocated some time to learn affixes while the rest did not do that. It clearly shows that the students are really in need of the support kit to learn and master affixes more effectively.

\section{Evaluation Test Analysis of Affixes Skills}

The second stage of the needs analysis encompasses the evaluation test of affixes skills given to 163 students from SJKT. In the learning of the second language, Corder (1973) categorised 
four errors made by the students which is the removal of unnecessary elements, the addition of inaccurate elements, the selection of inaccurate elements and wrong element arrangement. However, according to Corder, these categories are insufficient to explain more about errors, so he included errors for linguistic stages like morphology, syntax and lexicon. Several general errors obtained from the affixes skills evaluation test have been identified and analysed. Some of the factors that cause poor mastery in affixes are the influence of the mother tongue, environmental factor, confusion with the sounds of affixes, tnot mastering the meaning of affixes and not understanding the function of the affixes. Roshidah (2015) finds that the linguistic difference between the first language and the second language leads to the disturbance and problem to students in learning the second language. The lack of vocabulary has led second language students to choose inaccurate terms for the ideas they wish to convey (Hazlina\& Ang,2015). This finding is in line with the study by Nadwahand Nadhilah (2014) showing that the use of limited vocabulary among the studentneeds to be overcome as this aspect is crucial in the acquisition and mastery of language.

Table 5: The use of prefixes meN-, beR- , di- , peN- and teR-

\begin{tabular}{|l|l|c|c|}
\hline No. & \multicolumn{1}{|c|}{ Question } & Correct Answer (\%) & Wrong Answer (\%) \\
\hline 1 & $\begin{array}{l}\text { Amin sedang_ pokok bunga agar } \\
\text { tidak } \\
\text { layu. }\end{array}$ & $\begin{array}{c}\text { menyiram } \\
(29)\end{array}$ & $\begin{array}{c}\text { menysiram } \\
\text { (71) }\end{array}$ \\
\hline 2 & Encik Chong_di sawah padi. & bekerja & berkerja \\
& & $(27)$ & $(73)$ \\
\hline 3 & Rambut_oleh Vimala dengan kemas. & disikat & di sikat \\
& & $(27)$ & (73) \\
\hline 4 & Bapa Ajay_ getah. & penoreh & petoreh \\
& & terjatuh & ter jatuh \\
\hline 5 & Budak itu_ dari pokok rambutan. & $(30)$ & $(70)$ \\
\hline
\end{tabular}

Based on question (1), $29 \%$ of the students answered correctly and $71 \%$ of the students answered wrongly. Based on Corder's Error Analysis Theory (1973), the errors come from the morpho-phonology aspect, which is not removing the letter " $s$ " that should be removed. For question (2), $27 \%$ of the students answered correctly and the rest answered wrongly. Based on the Corder's Error Analysis Theory (1973), the answer 'berkerja' was considered wrong because it received an incorrect element, which is the prefix beR-which becomes be- when it meets with the word that ends with 'er' (Nik Safiah Karim et al., 2015). Thus, the second answer for the question is bekerja. In question (4), the correct answer is 'penoreh' and not 'petoreh'. This is because the root word that begins with ' $t$ ' will be replace with ' $n$ ' when it combines with the prefix peN- (Nik Safiah Karim et al., 2015). 72\% of the students gave a wrong answer for question four. In both the sentences, the use of the prefixes'di' and'ter' is incorrect because they are written separately from the verb. Thus, the errors found in question (3) and question (5) must be corrected into 'disikat' and'terjatuh'. 


\section{Diagram 2: The percentage of correct and wrong answers for the prefixes achievement test}

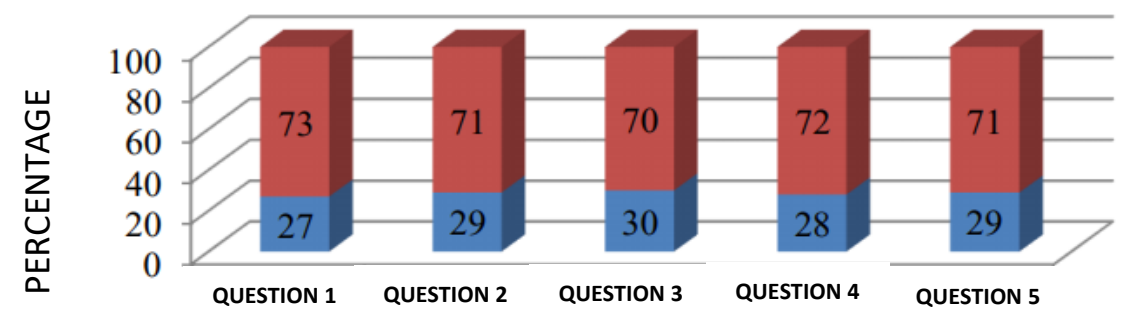

CORRECT

WRONG

QUESTION NUMBER

Table 6: The use of suffixes -i, -kan and -an

\begin{tabular}{|l|c|c|c|}
\hline No. & question & correct answer (\%) & wrong answer (\%) \\
\hline 1 & harta benda sekolah kita. & Sayangi & $\begin{array}{c}\text { Sayangkan } \\
(75)\end{array}$ \\
\hline 2 & ubat itu pada luka. & Sapukan & Sapuan \\
& & $(24)$ & $(76)$ \\
\hline 3 & air kopi ke dalam cawan. & Tuangkan & Tuangan \\
& itu diperbuat daripada buaian. & Buaian & Buaikan \\
\hline 4 & itu sangat tinggi. & $(25)$ & (75) \\
\hline 5 & & Bangunan & Bangunkan \\
& & $(23)$ & $(77)$ \\
\hline
\end{tabular}

Five questions above test the use of suffixes $-i,-k a n$ and - an. In question (1), the adjective 'sayang' can combine with the suffix -i to form a verb (Nik Safiah Karim et al., 2015). In the first question, 75\% students gave a wrong answer which is 'sayangkan' and based on the Error Analysis Theory, (1973), students selected a wrong answer as the selection of the element was inaccurate. In question (2) and question (3), the verbs 'sapu' and 'tuang' can be combined with the suffix -kan to form a verb. However, $24 \%$ of the students gave correct answers and $76 \%$ students gave wrong answers for question (2) and question (3). This clearly shows that most of the students had given a wrong answer as they chose an inaccurate element under Corder's Error Analysis Theory (1973). In question (4) and question (5), the verbs 'buai' and 'bangun'combine with the suffix -an to form a noun. A total of $75 \%$ of the students answered question 4 wrongly, while $23 \%$ of the students answered question 5 wrongly. The errors in both the questions stem from an inaccurate selection based on Corder's Error Analysis Theory (1973). 


\section{Diagram 3: Percentage of correct and wrong in the test of suffixes}

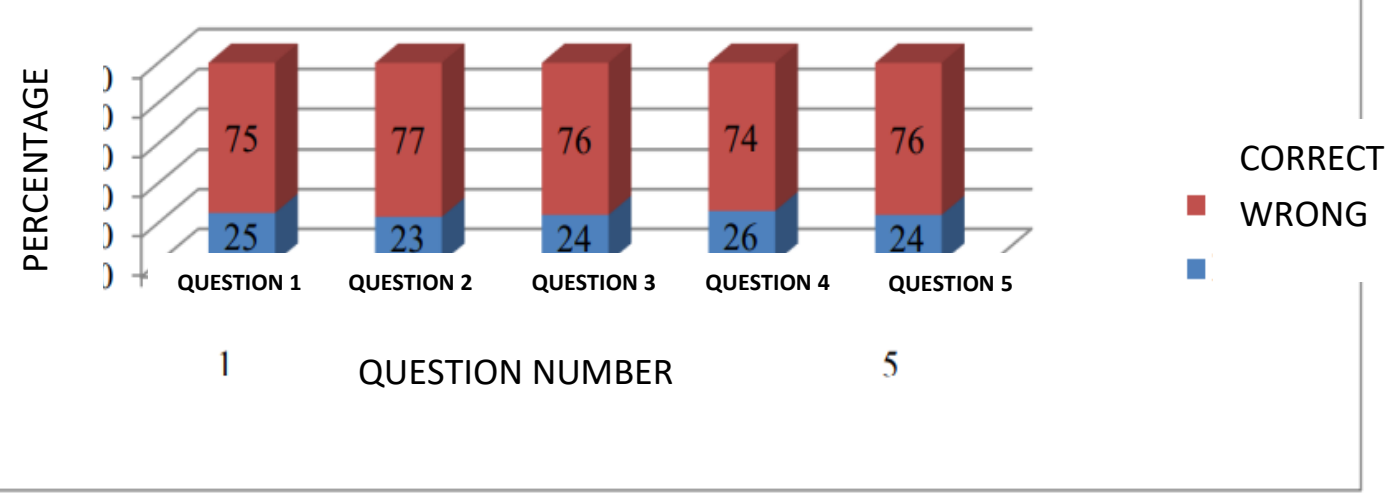

Table 7: The Use of affixes ke...an, peN...an, men...i and meN...kan

\begin{tabular}{|c|c|c|c|}
\hline No. & question & correct answer (\%) & wrong answer (\%) \\
\hline 1 & Kita perlu menjaga & $\begin{array}{c}\text { keselamatan } \\
\text { (19) }\end{array}$ & $\begin{array}{c}\text { keselamataan } \\
\text { (81) }\end{array}$ \\
\hline 2 & Murid-murid berkumpul di tapak. & $\begin{array}{c}\text { perhimpunan } \\
\text { (20) } \\
\end{array}$ & $\begin{array}{c}\text { perhimpunkan } \\
\text { (80) }\end{array}$ \\
\hline 3 & Kumar___ Internet dengan rajin. & $\begin{array}{l}\text { melayari } \\
\text { (21) }\end{array}$ & $\begin{array}{l}\text { melayarkan } \\
\text { (79) }\end{array}$ \\
\hline 4 & Alim___ kucing di bilik air. & $\begin{array}{c}\text { memandikan } \\
\text { (18) }\end{array}$ & $\begin{array}{c}\text { memandian } \\
\text { (82) }\end{array}$ \\
\hline 5 & Kakak John___ cincin pada jari ibunya. & $\begin{array}{c}\text { menyarungkan } \\
\text { (18) }\end{array}$ & $\begin{array}{c}\text { menysarungkan } \\
\text { (82) }\end{array}$ \\
\hline
\end{tabular}

The questions above have tested the use of affixes ke...an, peN...an, men...i and meN...kan. Based on Corder's Error Analysis Theory (1973), students chose wrong answers for the first question to the fourth question because of incorrect elements. The percentage of students who gave wrong answers for all four questions is between 79 and 82. Even so, in question (5), $18 \%$ of the students gave correct answers while the rest had given wrong answers. In question (5), students placed the affix 'meN...kan without doing any replacement process. This is because, the root word that begins with the consonant ' $s$ ' will undergo replacement with the consonant ' $y$ '. Thus, errors in question (5) must be corrected and become 'menyarungkan'. 


\section{Diagram 4: Percentage of correct and wrong in the test of affixes}

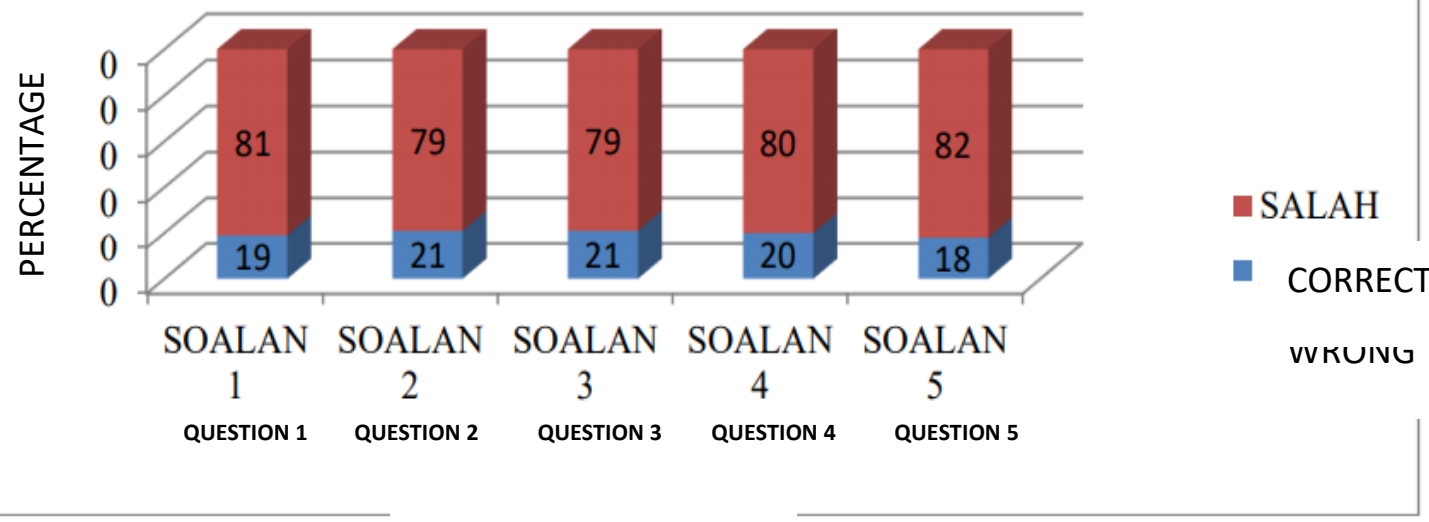

QUESTION NUMBER

Table 8: The use of borrowed affixes

\begin{tabular}{|l|l|c|c|}
\hline No. & \multicolumn{1}{|c|}{ question } & correct answer (\%) & wrong answer (\%) \\
\hline 1 & \multicolumn{1}{|c|}{ itu kakak Aisyah. } & $\begin{array}{c}\text { Jelitawan } \\
(18)\end{array}$ & $\begin{array}{c}\text { Jelitawati } \\
(82)\end{array}$ \\
\hline 2 & Adik bongsu Mei Ling belajar di_. & $\begin{array}{c}\text { prasekolah } \\
(19)\end{array}$ & $\begin{array}{c}\text { pra-sekolah } \\
(81)\end{array}$ \\
\hline 3 & itu belajar di Universiti Malaya. & $\begin{array}{c}\text { Mahasiswa } \\
(21)\end{array}$ & $\begin{array}{c}\text { Maha siswa } \\
(79)\end{array}$ \\
\hline 4 & $\begin{array}{l}\text { Semua murid patut mematuhi } \\
\text { Sekolah. }\end{array}$ & $\begin{array}{c}\text { tatatertib } \\
(19)\end{array}$ & $\begin{array}{c}\text { tata tertib } \\
(81)\end{array}$ \\
\hline 5 & $\begin{array}{l}\text { Sri Agung negara kita ialah Tan } \\
\text { P.Ramlee. }\end{array}$ & $\begin{array}{c}\text { Seniman } \\
(20)\end{array}$ & $\begin{array}{c}\text { Seniwan } \\
(80)\end{array}$ \\
\hline
\end{tabular}

Diagram 5: Percentage of correct and wrong in the test of borrowed affixes

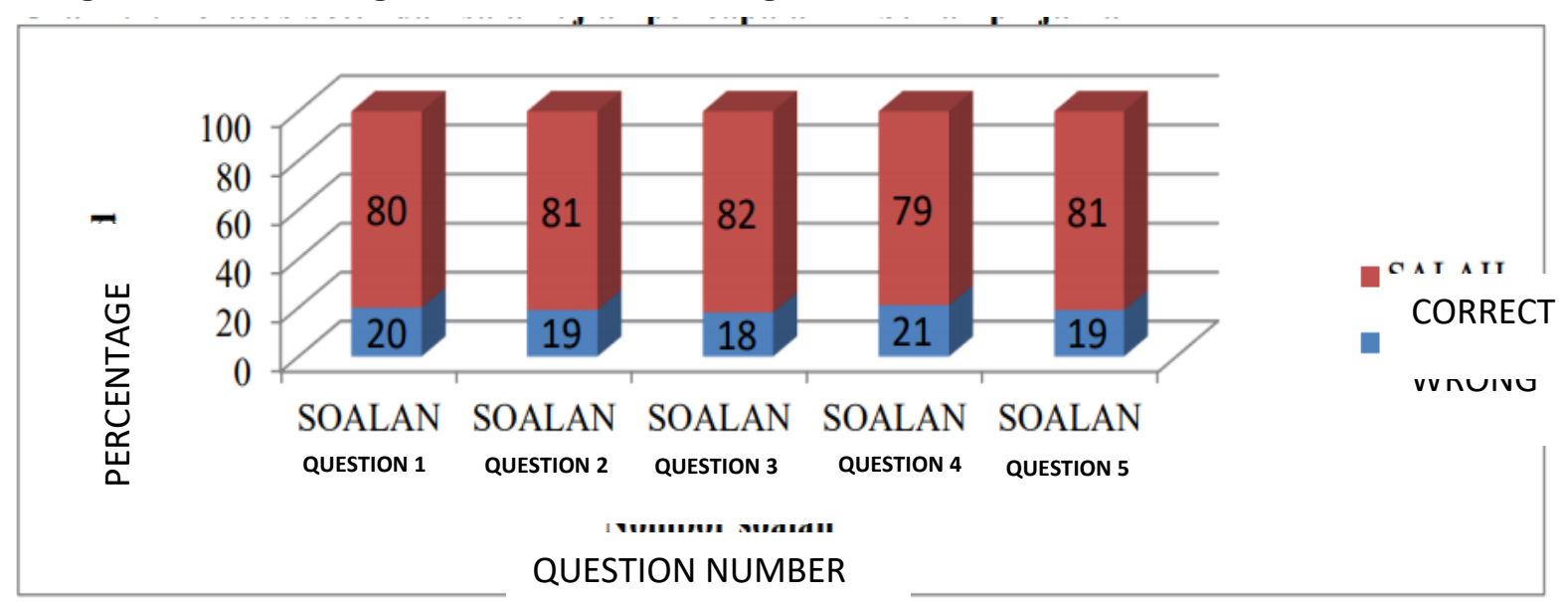


All the five questions above tested the use of borrowed affixes contained in the Malay Language paper for Year $5 \mathrm{SJK}$. In this question, two aspects in the Corder's Error Analysis Theory (1973) can be identified that is through the incorrect choice of element involving the first and the fifth questions whereas the wrong arrangement can be seen in question two to question four. In question (1), $82 \%$ students chose wrong answer because they were confused with the borrowed affixes 'wan' and 'wati'. Based on students' existing experience, borrowed affix 'wan' refers to the male and most students had selected a wrong answer which is 'jelitawati'. In question (2), question (3) and question (3), borrowed affixes 'pra', 'maha' and 'tata' should be written close together with the root words. Thus, the errors in the question should be corrected into 'prasekolah', 'mahasiswa' and 'tatatertib'. In question (5) the wrong answer 'seniwan' must be replaced with 'seniman' due to the fact that 'man' is used for the root word that ends with the letter ' $i$ ' (Karim et al., 2015).

\section{Interview Findings}

The third stage of the needs analysis involves an interview with Head of the Malay Language Teachers. A set of questions containing three themes is distributed to five Heads of the Malay Language teachers. Straus and Corbin (1998) stated that the use of the qualitative method can be used to get a better understanding about a phenomenon that has yet to be known in further detail. Thus, researcher used the semi-structured interview question answered by the Head teachers to know the needs to construct the affixes innovation kit based on the phenomenon based on the Head Teachers other than looking at the actual situation in further detail.

Thus, this stage seeks to answer the following question:

1.What is the view of the Head of the Malay Language teachers towards the use of the kit in support of the teaching and learning of affixes?

The semi-structured questions distributed to Head of the Malay Language teachers are based on three main sub-themes, namely the view of the head teachers towards games of affixes and her view of the role of the kit in supporting the teaching and learning of affixes, also her view of the student-centered teaching activities on affixes

Theme 1: Can the support kit facilitate the teaching and learning of prefixes, suffixes, affixes and borrowed affixes?

All the respondents are very satisfied with the support kit that can facilitate the teaching and learning of prefixes, suffixes, affixes and borrowed affixes. Two respondents stated that the support kit was able to eliminate students' boredom whereas three respondents stated that the kit has the potential to produce active and creative students. For example, respondent 2 (R2) stated that:

R2 : "This kit can help student learning actively. Students enjoyed it. It gives an added value to the teaching technique and students have the confidence to carry out the teaching and learning of affixes based on the materials given."

Respondent 3 (R3) and 4 (R4) highlighted that the innovation kit is fun to the children and they can still excel in their learning through play. 
R3: "In my opinion, this kit helps me to teach students at my school because the technique in this kit helps students to become interested to learn."

R4: "The understanding and mastery of affixes of intermediate students can be improved with the help of the support kit."

Theme 2: Does the teacher need an alternative material in the form of games to diversify the technique of teaching affixes?

All the respondents expressed their intention to get an alternative material in the form of games to diversify their techniques in teaching affixes. They also hoped that the use of the text book is reduced- as stated by Ghazali Yusri et al. (2012) the use of the textbook only serves as guidance and not the end result of the learning. Meanwhile, respondent 5 (R5) confidently stated that:

R5: "Game activities can instil the interest and spur high motivation among students to learn affixes."

Respondent 2 (R2) held the view that the games can entertain the students and at the same time encourage them to learn hard about affixes.

R2: "Games give the students the opportunity to move freely, get exposed to real activities and train them to focus on their learning."

Theme 3: Do teaching of affixes need to be student-centered and teachers serve as facilitators?

All the respondents are anonymous with the statements. They are of the opinion that the teaching activities that are really suitable with the students can help the teacher guide the students in catapulting themselves into improving and mastering affixes. Following this, respondent 1 (R1), respondent 2 (R3) and respondent 4 (R4) stated that:

R1: "The concept of building the teaching activity needs to be based on the $21^{\text {st }}$ century learning focusing on the students and minimal teacher's involvement in the process of teaching and learning affixes."

R3: "The student-centered teaching activity is able to produce students who can broaden their social skills. They can also inculcate leadership skills and a healthy spirit of competitiveness."

R4: "Student-focused teaching activities give an opportunity to the students to train and master various language skills. Teacher can also check and tend to students' weakness and errors in affixes."

\section{Conclusion}

The needs analysis study requires the researcher to conduct information gathering about the context and situation from both teachers and students. In the context of the study, researcher gathers information about teacher's existing practice and students' needs so that the information obtained can help researcher produce the affix word innovation kit that can help solve the current problems that teachers and students are facing. The outcome of the analysis 
suggests that the affix word innovation kit must be developed to help them so that the teaching and learning of affixes can be done better. The study finding shows that most teachers agree with the importance of the affix word innovation kit that focuses more on games and the benefit of this approach to primary school students. To solve the issue among the students and teachers, materials in the form of the affix word innovation kit have to be developed to increase the knowledge and skills in planning the teaching and learning of affixes more efficiently and based on what the students need. According to Branch (2009), a good teaching material is one that can brush up one's ability by increasing the knowledge and skills. Based on the outcome from the needs analysis, the development of affix word innovation kit must consider the aspect that can increase the knowledge and skills of the teachers to fulfil the learning objective based on student needs and knowledge about their language capabilities. It also has to consider the aspect that can accentuate teachers' skills by means of using the teaching aids, techniques that can engage the students and guiding the students in small groups. The finding also shows that teacher's readiness to use the support kit in teaching and learning affixes is very good. They really need the teaching resource and material in the form of affix word innovation kit that details the teaching and learning method. This teaching guidance should contain the teaching and learning of games activities that are fun and take into account students' language abilities. In brief, the developed innovation kit must take into account the suggestions and specification, such as easily available, explaining the preparation of the teaching materials and how the games work. Due to this, immediately after the needs analysis process, researcher should be able to determine the teaching that can solve problems and suggest strategies based on the empirical data so that teaching can be done better (Branch, 2009). The finding from the needs analysis shows that the innovation kit for teaching and learning affixes has the potential to be used by students and teachers in primary schools.

\section{Acknowledgment}

This research was funded by Socio-Economic Development of the Indian Community Unit, Prime Ministers' Department (SEDIC). The authors would like to express their sincere gratitude to Malay language School Improvement Specialist Coaches and excellent Malay language teachers for their time, contribution, and extended support throughout this study.

\section{References}

Alhaadi, I., \& Zaitul, A. (2018). Analisis Kesilapan dalam penulisan pelajar bahasa kedua dari aspek morfologi. Jurnal Lingusitik., 22(1), 24-31.

Aliza, A.,\& Zamri, M.(2016). Pembangunan dan kebolehgunaan modul berasakan bermain bagi pembelajaran kemahiran Bahasa Melayu kanak-kanak prasekolah. Jurnal Pendidikan Bahasa Melayu . 6(1), 16-29.

Amirra, S., \& Vijayaletchumy, S. (2019). Kesilapan penggunaan Imbuhan Awalan and Imbuhan Akhiran dalam kalangan murid Sekolah Jenis Kebangsaan Tamil berdasarkan Teori Analisis Kesilapan Corder (1973). International Journal of the Malay World and Civilisation 7(1), 3- 13.

Branch, R. M. (2009). Instructional design: The ADDIE approach. Springer.

Chew, F. P. (2016). Masalah pembelajaran Bahasa Melayu dalam kalangan murid Cina sekolah rendah.Jurnal Pendidikan Bahasa Melayu .

Corder, S. P. (1973). Introducing applied linguistics. Peguin Book Ltd.

Cresswell, J. W., \& Clark, P. V. (2007). Designing and conducting mixed method research. SAGE Publications. 
DeWitt, D. (2010). Development of collaborative Learning module on nutrition for Form Two students. [Tesis PhD. Fakulti Pendidikan, Universiti Malaya].

Gagne, M. R., Wager, W. W., Golas, K. C., \& Keller, J. M. (2005). Principles of instructional design (5th ed.).Belmont, Wadsworth.

Goh, Y. S., \& Ng, A. (2004). The bumiputra students' attitude in learning Mandarin at UiTM campus Terengganu, Malaysia. The international colloquium on language, attitudes and education in multilingual cities.

Hazlina, A., \& Ang, L. H. (2015). Kesilapan pemilihan dan pembentukan kata dalam terjemahan bahasa Perancis. GEMA Online Journal of Language Studies.

Jorge F. (2016). Gamification and game-based learning: Two strategies for the 21st Century Learner. School of Social and Human Sciences, Universidad del Este, Carolina, Puerto Rico.

Jusoh, A. B. (2008). Hubungan amalan pengurusan kualiti menyeluruh dengan tahap pemindahan teknologi: Suatu study emperikal mengikut perspektif penyelidik universiti. [Unpublished PhD Thesis]. Universiti Utara Malaysia.

Jyh, W. S. (2005). Evolusi dan evolusi semula bahasa. Dewan Bahasa. September, 17-21.

Kementerian Pelajaran Malaysia. (2011). Dokumen Standard Kurikulum dan Pentaksiran Bahasa Melayu (SJKT), Bahagian Pembangunan Kurikulum, Putrajaya.

Kivinen, Viivi \& Pollari, Saara. (2018).Teaching Finnish as a second language with new practice material.Laurea University of Applied Sciences.

Krohn. (2008). The Long View of Crime: A Synthesis of Longitudinal research, 128-160.

Maja, B. (2019). Does game based teaching have an impact on students creativity?. Fakulti Sains Pendidikan, Universiti Osijek, Croatia.

Marzalina, M. (2004). Stail pembelajaran Bahasa Melayu sebagai bahasa asing dalam kalangan pelajar luar Negara [Tesis sarjana yang tidak diterbitkan]. Universiti Putra Malaysia.McKillip, J. (1987). Need analysis: Tools for the human service and education. Applied social research methods series, 10. Sage Publications Inc.

Miles, M. B., \& Huberman, A. M. (2014). Qualitative data analysis:An expanded sourcebook ( $2^{\text {nd }}$ ed.). SAGE.

Money, J. N. J. S. (2004). Kesilapan bahasa dalam karangan murid Tamil yang mempelajari Bahasa Melayu di sekolah menengah [Tesis PhD. yang tidak diterbitkan]. Universiti Putra Malaysia.

Nadwah \& Nadhilah. (2014). The issue pertuturan dalam bahasa Arab sebagai bahasa kedua. GEMA Online ${ }^{\circledR}$ Journal of Language Studies, 14(1), February 2014.

Nathesan. (2010). Beberapa persoalaan penggunaan Bahasa Melayu dan penyelesaiannya. Edisi kedua. Dewan Bahasa dan Pustaka.

Nazri, A., \& Rosman, I. (2014). Transformasi bentuk pentaksiran dan penilaian dalam buku teks: aplikasi interpretive structural modelling (ISM).

Noor, H., \& Yahya, O. (2018). Strategi pembelajaran kemahiran menulis Bahasa Melayu sebagai bahasa kedua dalam kalangan pelajar Melanau daerah Daro. Jurnal Pendidikan Bahasa Melayu . 8(1), 33-41.

Noor, H., \& Yahya, O. (2016). Keberkesanan peta bulatan dan peta alir dalam meningkatkan penguasaan menulis karangan naratif murid-murid Cina. Jurnal Pendidikan Bahasa Melayu; Bahasa Melayu Education (MyLEJ), 6(2), 68-77.

Noor, Z. (2015). Bahasa antara dalam pembelajaran Bahasa Melayu sebagai bahasa kedua [Tesis Doktor Falsafah, Universiti Putra Malaysia]. 
Norhafisya, Z. (2017). Kaedah LATIM sebagai inovasi pendidikan dalam meningkatkan penguasaan penggunaan Imbuhan Awalan meN. Jurnal Bahagian Teknologi Pendidikan, Ministry of Education Malaysia.

Norsidah, A., Jamaludin, B.,\& Fairose, S. (2010). Kelemahan tatabahasa pelajar Cina dalam penulisan karangan pada peringkat menengah rendah. Prosiding Seminar Antarabangsa Pendidikan Bahasa Melayu , 12-18 Jun.

Nur, H. (2012). Keberkesanan penggunaan kaedah bermain dalam pengajaran dan pembelajaran asuhan Tilawah al-Quran Tahun 4. Seminar Penyelidikan Tindakan IPG, (September), 34-44.

Nur, K., Abu, B., \& Zamri, A. (2014). Penggunaan strategi belajar bahasa dalam pembelajaran bahasa Arab sebagai bahasa kedua: Satu Sorotan. Prosiding Seminar Pengajaran \& Pembelajaran Bahasa Arab, 2014 , 1-4.

Nur, S. (2014). Penguasaan Bahasa Melayu sebagai bahasa kedua dalam kalangan pelajar etnik Cina di sekolah menengah persendirian Cina: satu study kes. Masters thesis, Universiti Malaysia Sabah.

Nurul, A., \& Maisarah, H. (2018). Pengajaran dan pembelajaran Imbuhan melalui pendekatan pembelajaran aktif. Seminar Bahasa Melayu 2018, 19, 235- 247.

Nurul, H., Rafidah, A. K., Farahidatul, A., \& Zainab, M. (2017). Keberkesanan penggunaan kaedah permainan bahasa dalam pembelajaran penterjemahan peribahasa. Jurnal Antarabangsa Alam Dan Tamadun Melayu, 5(3).

Ooi, C. H. (2018). Keberkesanan modul dalam meningkatkan penguasaan Imbuhan meN- dan PeN-urid SJKC [Tesis ljazah Doktor Falsafah,Universiti Teknologi Malaysia].

Ooi, C. H., \& Vijayaletchumy, S. (2017). Faktor timbulnya pengaruh bahasa pertama dalam mempelajari Bahasa Melayu sebagai bahasa kedua. Ulum Islamiyyah, 20, 35-45. Universiti Sains Islam Malaysia.

Ramlan, M., \& Ghazali, D.(2018). Aplikasi kaedah Fuzzy Delphi dalam penyelidikan Sains Sosial. Penerbit Universiti Malaya, Kuala Lumpur.

Reinbold, S. (2013). Using the ADDIE model in designing library instruction. Medical Reference Services Quarterly, 32(3), $244-256$.

Richey, R. C., \& Klein, J. D. (2007). Design and development research: Methods, Strategies, and issues.Lawrence Erlbaum Associates, Publishers.

Roshidah, H. (2015). Analisis penguasaan bunyi vokal bahasa Perancis oleh pelajar Melayu. GEMA Online Journal of Language Studies, 15(3).

Saedah S. J., Norlidah, A., DeWitt, D., \& Zaharah, H. (2013). Design and developmental research:Emergent trends in educational research. Pearson Malaysia.

Salinah, J., \& Rohaidah, H.(2016). Kesilapan Bahasa Melayu dalam kalangan pelajar-pelajar Universiti Kebangsaan Yunnan di Akademi Pengajian Melayu. Jurnal Melayu. 15(2), 196209.

Sanchez-Franco, M. J., \& Roldán, J. L. (2010). Expressive aesthetics to ease Perceived community support: Exploring personal innovativeness and routinised behaviour as moderators in Tuenti. Computers in Human Behavior, 26(6), 1445-1457.

Siti, B. (2011). Analisis Kesilapan tatabahasa Bahasa Melayu dalam karangan pelajar asing di sebuah institusi pengajian tinggi awam. $2^{\text {nd }}$ International Language Conference 2011, IIUM

Siti, S., \& Melor, M. (2014). Attitudes and motivation towards learning English among FELDA school students. Australian Journal of Basic and Applied Sciences, 8(5), 1-8. 
Sri, R., \& Zawiyah, K. N. (2016). Penggunaan kad permainan bahasa dalam pengajaran dan pembelajaran Bahasa Melayu . Seminar Bahasa Melayu , 359-368.

Turner, D. W. (2010). Qualitative interview design: A practical guide for novice investigators. The Qualitative Report, 15(3), 754-760.

Vijayaletchumy, S., \& Siva, P. I. (2020). Keberkesanan Kit Inovasidalam meningkatkan penguasaan Imbuhan murid SJK. International Conference on Trends In Technology, Business, Education \& Social Research (ICTTBESR2020

Wan, Z., \& Amanah, M. (2015). Kesilapan ejaan di papan tanda. Jurnal Bahasa Memartabatkan Bahasa Melayu MBahasa Melayu, 50-57. Kota Samarahan: IPG Kampus Tun Abdul Razak.

Yong, C. C., \& Vijayaletchumy, S.(2012). Analisis kesilapan dalam Pembelajaran Bahasa Melayu oleh pelajar asing. GEMA Online ${ }^{T M}$ Journal of Language Studies, 12(2), May 2012.

Zalina, M. (2017). Kesilapan tatabahasa Bahasa Melayu dalam kalangan pelajar. LSP International Journal, 4(1), 23-35.

Zamri, M., \& Mohamed, A. (2006). 'Kesilapan bahasa dalam penulisan karangan pelajar Bukan Melayu: Satu study kes dalam Zamri Mahamod. Psikolinguistik dalam pengajaran dan pemelajaran Bahasa Melayu (hlm 214-262). Karisma Publications Sdn Bhd.

Zanariah, A. (2017). Pembangunan modul pedagogi kelas berbalik berasaskan pembelajaran reflektif untuk politeknik primier [Tesis Phd. Universiti Malaya]. 